\title{
THE USE OF MICROTEHNOLOGIES PROCESSING ON WATER AERATION PLANTS CONSTRUCTION
}

\author{
Rareș Păun, PhD Student Eng. ${ }^{1}$, Prof. Nicolae Băran, PhD Eng. ${ }^{2}$, \\ Albertino Roza, PhD Student Eng. ${ }^{3}$, Beatrice Tănase, PhD Student Eng. ${ }^{4}$, \\ Rasha Cusma, PhD Student Eng. ${ }^{5}$ \\ 1,2,3,4,5,6 Politehnica University of Bucharest \\ Splaiul Independenței $\mathrm{nr}$. 313, sector 6, Bucharest \\ 1,3inregistrare@gmail.com ,2n_baran_fimm@yahoo.com, 4inregistrare@gmail.com, 5tanaseelenab@gmail.com, \\ 6mlisanrasha@yahoo.com
}

\begin{abstract}
The paper presents how advanced technologies can serve to solve some water aeration plants problems. The construction of fine air bubbles generators is needed for an efficient water aeration. The main element of those generators is the orifice plate for air injection in the water mass. The research team has built a fine bubble generator with 152 orifice plate $(\varnothing 100 \mu \mathrm{m})$ which can be achieved through spark-erosion or microvoids technologies. The theoretical and experimental researches on increasing the dissolved oxygen concentration in water have led to satisfactory results.
\end{abstract}

Keywords: Water Aeration, Air Microbubbles Generators, Air Injection, Dissolved Oxygen Concentration, Micro Technologies.

\section{Introduction}

Of the power consumption of a water treatment plant, one part, about $50 \%$, is used to aerate the water. Aeration (oxygenation) is currently performed with porous diffusers made of ceramic or glass; they do not emit bubbles of equal size and emit non-uniformly on the diffusers surface. In the laboratories of "Politehnica" University of Bucharest were designed and built fine bubble generators (F. B. G.) on which the orifices plate is made by sparkerosion $(\varnothing<0.5 \mathrm{~mm})$. In this case, the orifices are equal and evenly distributed in the xOy plane.

Two types of technologies can be distinguished for performing orifices in the microbubbles generator plate (M.B.G.):
I) Micro technologies machining that can create orifices of $\emptyset>1 \mu \mathrm{m}$;

II) Nanotechnologies machining producing orifices of $\emptyset<1 \mu \mathrm{m}$;

It is known from the literature that with the reduction of the air bubble diameter, the oxygen transfer rate to the water is higher; the diameter of the air bubble is a function of the orifice diameter in the perforated plate of M.B.G.

The gas bubbles immersed in water come from the following sources:

- Atmospheric air (21\% 02 + 79\% N2);

- Atmospheric air + oxygen from the cylinder;

- Low nitrogen-containing air (oxygen concentrators).

These gas bubbles can be classified as follows (Fig. 1):

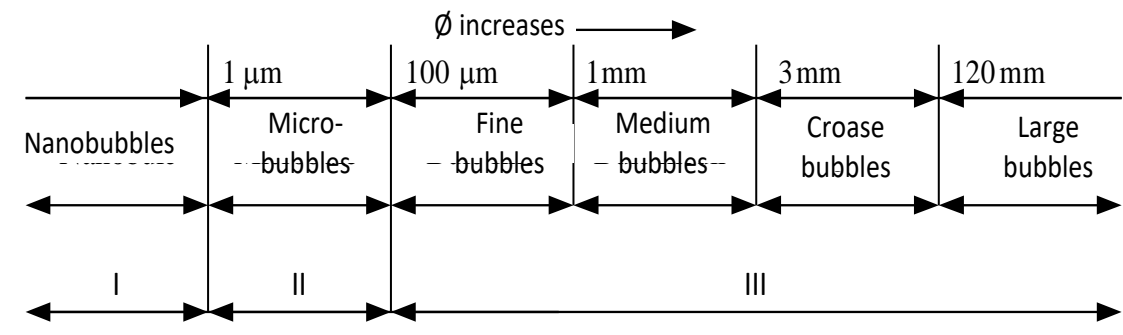

Figure 1: Classification of gas bubbles according to their diameter (Ø): I - the area where the gas bubbles can be observed under the microscope;II - the area where gas bubbles can be observed with difficulty;III - the area where gas bubbles can be observed with the naked eye 


\section{Construction of the Microbubbles Generator}

To obtain fine bubbles or microbubbles, the diameter of the orifices should be as small as possible $(\mathrm{d} 0<1 \mathrm{~mm})$ and the distribution of the orifices in the plate should be uniform.

These two conditions can be achieved with the help of advanced technologies or modern microprocessing technologies [1] [2] [3]:

- Spark erosion processing;

- Electrochemical processing;

- Laser processing;

- Electron beam processing;

- Drills in coordinate, with $\varnothing 0.5 \mathrm{~mm}$ drills.

The microbubbles generator has a dispersion element, a metal plate of rectangular shape, which is called M.B.G.

The thickness plate $\mathrm{s}=2 \mathrm{~mm}$ has 152 orifices with a diameter $\mathrm{d} 0=0.1 \mathrm{~mm}$ and the distance between the orifices $\mathrm{d}=2 \mathrm{~mm}$. Thus, the two conditions [4] are met:

$$
\begin{aligned}
& \frac{\mathrm{s}}{\mathrm{d}_{0}}>3 \rightarrow \frac{2}{0.1}=20 \\
& \frac{\mathrm{d}}{\mathrm{d}_{0}}>8 \rightarrow \frac{2}{0.1}=20
\end{aligned}
$$

The bubble columns at the exit of the perforated plate create a bubble curtain similar to a planar jet having a rectangular cross-section.

From previous research, taking into account the dimensions of the water tank and the height of the water layer, a section of the air outlet in water equal to $1.2 \cdot 10^{-6} \mathrm{~m}^{2}$ was chosen. For $\mathrm{d}_{0}=0.1 \mathrm{~mm}$, the following number of orifices resulted [5]:

$$
\mathrm{n}=\frac{\mathrm{A}}{\left(\pi \cdot \mathrm{d}_{0}^{2}\right) / 4}=\frac{1,2 \cdot 10^{-6}}{\frac{\pi \cdot\left(0,1 \cdot 10^{-3}\right)^{2}}{4}}=152
$$

Figure 2 shows a plan view of M.B.G. of rectangular shape.

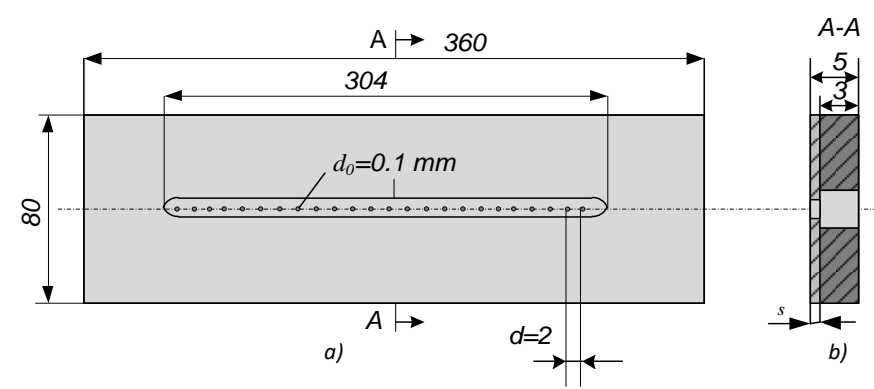

Figure 2: M.B.G. perforated plate: a) plane view; b) cross section

Figure 3 shows the constructive solution of the microbubbles generator (M.B.G.) to be used in experimental researches.

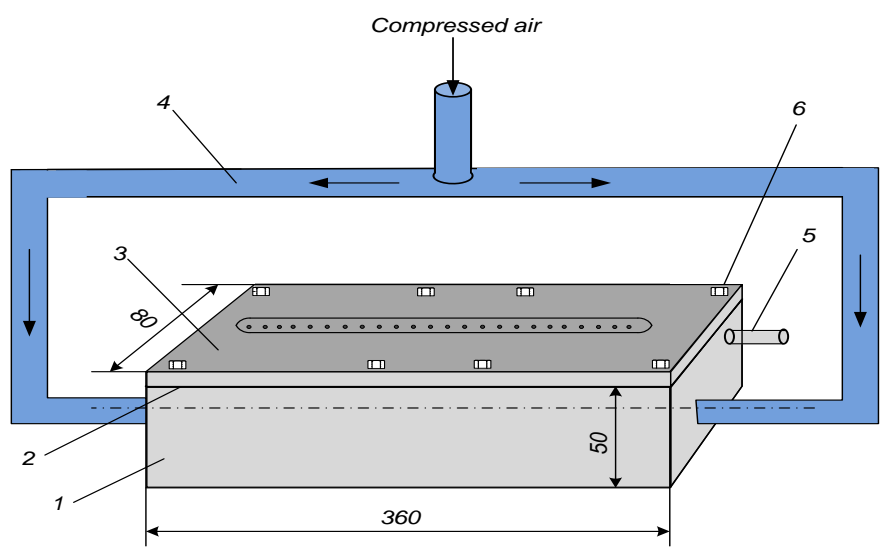

Figure 3: Air microbubbles generator: 1 - compressed air tank; 2 - sealing gasket; 3 - the orifice plate; 4 - $18 \mathrm{~mm}$ pipe with compressed air; 5 - connection for the measurement of the air pressure in the tank; 6 - perforated plate fastening screws

The orifices in the perforated plate were made by micro drilling machine KERN Micro. This machine has an accuracy of $\pm 0.5 \mu \mathrm{m}$ and can process parts with a height of $220 \mathrm{~mm}$ and a diameter of $350 \mathrm{~mm}$.
In order to achieve this M.B.G., which is an original constructive solution, it took a theoretical and experimental work revealed by [6] [7]. 


\section{Numerical Integration of the Oxygen Transfer Rate to Water}

The equation of the oxygen transfer rate in water is [5]:

$$
\frac{\mathrm{dC}}{\mathrm{d} \tau}=\mathrm{a} \cdot \mathrm{k}_{\mathrm{L}}\left(\mathrm{C}_{\mathrm{s}}-\mathrm{C}\right)
$$

Relation where: C - the dissolved oxygen concentration at time $\tau$; $\mathrm{ak}_{\mathrm{L}}$ - volumetric mass transfer coefficient; $\mathrm{C}_{s}$ - the concentration of oxygen in water at saturation.

The values of $\mathrm{ak}_{\mathrm{L}}$ and $\mathrm{C}_{\mathrm{s}}$ are constant in time. If limit conditions $C=C_{0}$ are imposed for $\tau=0$, equation (4) can be integrated [6] [7]:

$$
\begin{aligned}
& \int_{\mathrm{C}}^{\mathrm{C}_{0}} \frac{\mathrm{dC}}{\mathrm{C}_{\mathrm{s}}-\mathrm{C}}=\int_{0}^{\tau} \mathrm{a} \cdot \mathrm{k}_{\mathrm{L}} \mathrm{d} \tau \\
& \left.\ln \left(\mathrm{C}_{\mathrm{s}}-\mathrm{C}\right)\right|_{\mathrm{C}} ^{\mathrm{C}_{\mathrm{s}}}=\mathrm{a} \cdot \mathrm{k}_{\mathrm{L}} \tau+0+\mathrm{ct}
\end{aligned}
$$

It results:

$$
\begin{aligned}
& \mathrm{C}=\mathrm{C}_{\mathrm{s}}-\left(\mathrm{C}_{\mathrm{s}}-\mathrm{C}_{0}\right) \cdot \mathrm{e}^{-\mathrm{a} \cdot \mathrm{k}_{\mathrm{L}} \cdot\left(\tau-\tau_{0}\right)} \\
& \tau_{0}=0
\end{aligned}
$$

In the case of the study, the air is continuously introduced into the tank for 120 ', so the regime is non-stationary, the dissolved oxygen concentration will increase in time. In non-stationary regime, the measured amount will be the concentration of oxygen in water in time. Measurements: water and air temperature, gas flow rate at the tank inlet and gas pressure in the M.B.G. body. The tank is shown in Figure 4.

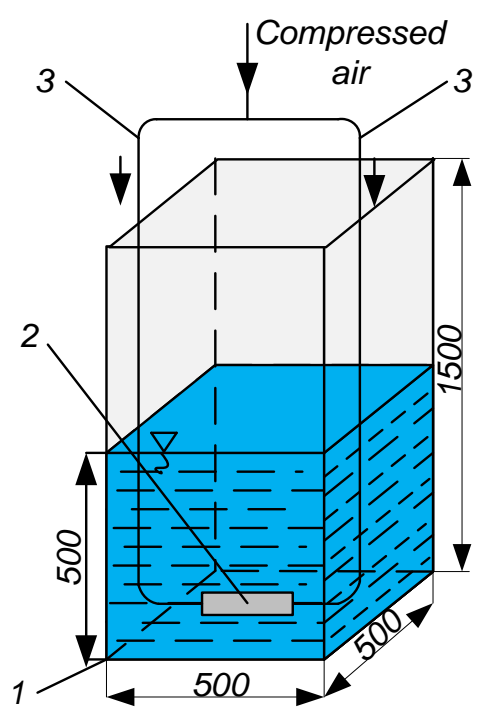

Figure 4: Water tank into which the microbubbles generator is inserted; the generator is fixed; $V=0.375$ m3; $\mathrm{VH} 2 \mathrm{O}=0.125 \mathrm{m3} ; 1$ - transparent plexiglass tank;

2 microbubbles generator (M.B.G.); 3- air supply pipes

\section{The Development of a Program for Calculating the Function $\mathrm{C}=\mathrm{F}(\mathrm{T})$ for Different Compositions of the Gas Injected into the Water}

The equation of the oxygen transfer rate in water (7) is resumed:

$$
\mathrm{C}=\mathrm{C}_{\mathrm{s}}-\left(\mathrm{C}_{\mathrm{s}}-\mathrm{C}_{0}\right) \cdot \mathrm{e}^{-\mathrm{a} \cdot \mathrm{k}_{\mathrm{L}} \cdot\left(\tau-\tau_{0}\right)}
$$

In this equation must be known:

$\mathrm{C}_{0}$ - the initial concentration of dissolved $\mathrm{O}_{2}$ in water; $\mathrm{C}_{\mathrm{s}}$ - dissolved $\mathrm{O}_{2}$ saturation concentration in water for a given water temperature; $\mathrm{ak}_{\mathrm{L}}$ - the oxygen transfer volumetric coefficient $\left[\mathrm{s}^{-1}\right]$ or $\left[\mathrm{min}^{-1}\right]$ determined by one of the chemical, electrical methods.

The values of $C=f(\tau)$ is calculated on the basis of a calculation program described below (see Figure 5) [7]:

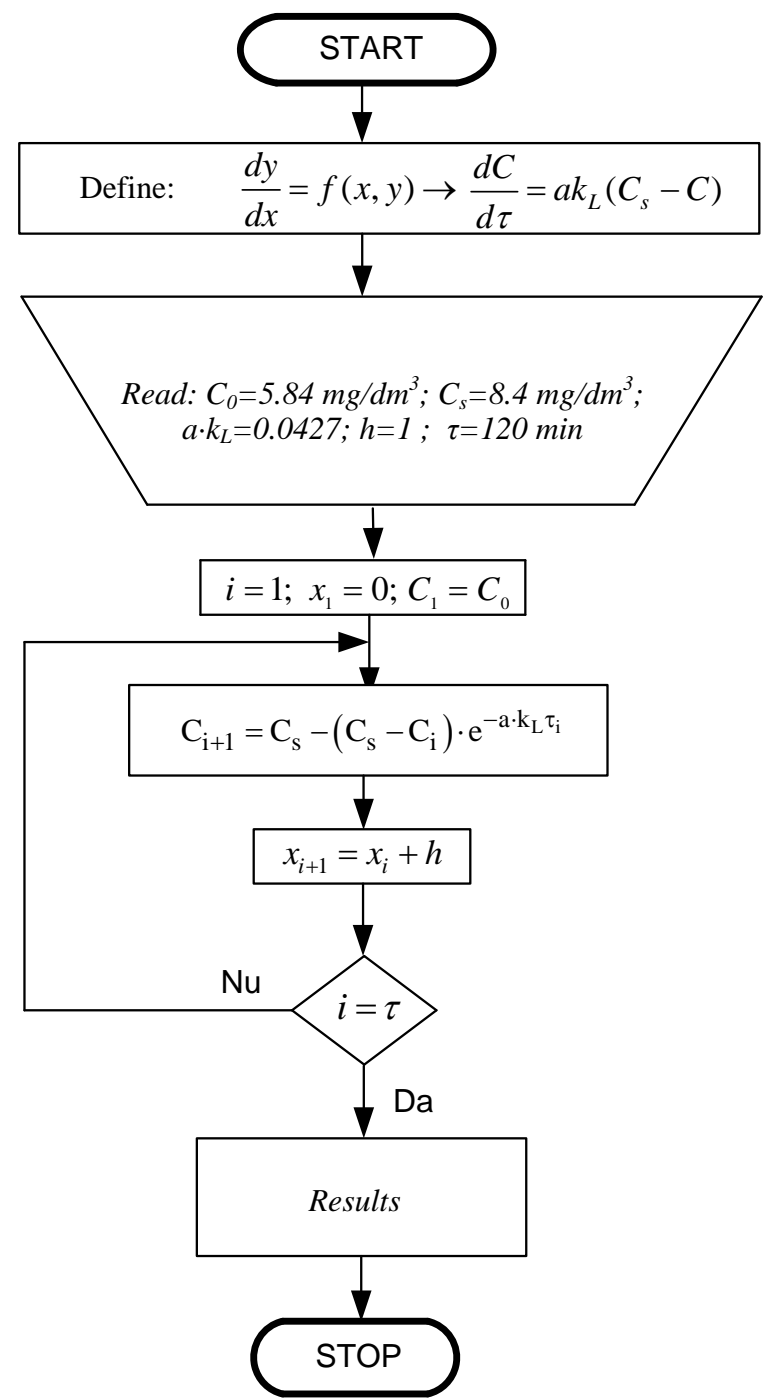

Figure 5: Logical diagram for the function: $C=f(\tau)$ 


\section{The Experimental Installation for the Injection of Air from the Atmosphere into the Water}

The purpose of the research is to validate the theoretical results previously obtained.

Figure 6 shows the sketch of the experimental installation.

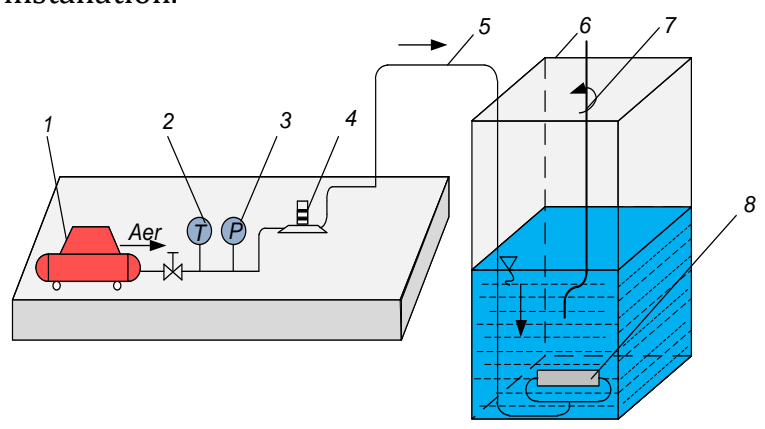

Figure 6: The experimental installation scheme for the injection of atmospheric air into water: 1 - air compressor; 2 - temperature measuring devices;

3 - gas pressure gauge; 4 -rotameter; 5 - pipe for the transport of the compressed air to the M.B.G.;

6 - parallelepiped water tank; 7 - oxygenometer probe; 8 - microbubble generator with 152 orifices $\emptyset 0.1 \mathrm{~mm}$

During the experimental researches, the following values will be maintained: gas pressure at the entrance at the M.B.G., gas flow rate, and hydrostatic load.

At 15 minute intervals the air supply is interrupted and the oxygenometer probe (7) is inserted; the signal taken from the probe is processed in the microcomputer and digitally displayed on the microcomputer screen.

The operation of M.B.G. of rectangular shape with 152 orifices of $\emptyset 0,1 \mathrm{~mm}$ are shown in Figure 7.

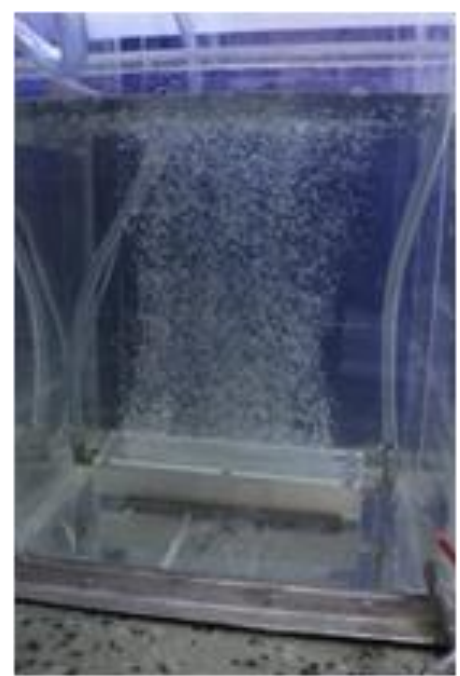

Figure 7: M.B. G. with 152 orifices $\emptyset 0.1 \mathrm{~mm}$ in operation
M.B.G. is provided with a perforated plate, with $\emptyset 0.1$ $\mathrm{mm}$ orifices performed by micro drilling.

\section{Comparison of the Theoretical Results with the Experimental Obtained Data}

Following the computation program in Figure 5, a series of data resulted. Based on these data, the curve (1) of Figure 8 was plotted.

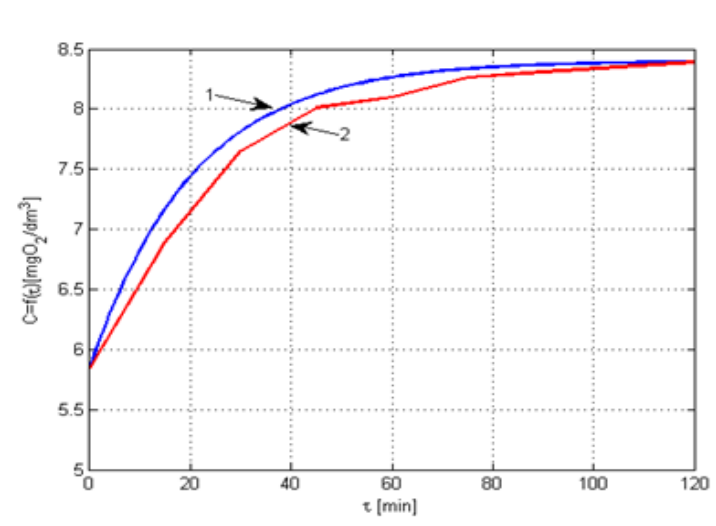

Figure 8: Fig. 8.Dissolved 02 concentration for atmospheric air: 1- curve 1 based on theoretical data; 2-curve 2 based on experimental data

After the experimental research, the curve (2) of Figure 8 was plotted. From Figure 8 one can observe that there is a very small difference between the theoretical and the experimental data. The obtained results are similar to other works in the field [8] [9] [10].

\section{Conclusions}

Constructing a micro-bubble generator, where the perforated plate has $\emptyset 100 \mu \mathrm{m}$ orifices, is a first in the field of water aeration;

The smaller the diameter of the air bubble in the water, the higher the term akL, so the oxygen transfer rate will increase;

In [7] the theoretical and experimental results for fine bubble generators are com-pared. The perforated plate has orifices of $\emptyset<0.5 \mathrm{~mm}$ and it is shown that the most efficient generator is the one with the smallest diameter orifice;

The loss of pressure in a porous diffuser is 1.2 $\mathrm{mH} 20$ [4], and at a M.B.G. is $0.02 \mathrm{mH} 20$; as a result, the energy consumed for the air compression is much lower in the case of M.B.G.

The theoretical and experimental researches presented above leads to a very good coincidence, which reveals the correctness of these researches. 


\section{References}

[1] Gavrilaș. I., Marinescu. ～N. I.: Prelucrări neconvenționale în construcția de mașini, Editura Tehnică, București, (1991).

[2] Nanu, A.: Tehnologia materialelor, Editura Didactica și Pedagogică, București(1977).

[3] Ceaușescu, N., Popescu, I.: Tehnologii neconvenționale, Editura Scrisul Românesc, Craiova, (1982).

[4] Oprina, G., Pincovschi, I., Băran, Ghe.: Hidro-GazoDinamica Sistemelor de aerare echipate cu generatoare de bule, Ed. POLITEHNICA PRES, București(2009).

[5] Dobrovicescu, Al., Băran, N., et al.: Colecția „Bazele Termodinamicii tehnice”, vol. I Elemente de termodinamică tehnică", Editura POLITEHNICA PRESS, București(2009).
[6] Mateescu, G.: Doctoral Thesys, Hidro-gazo dinamica generatoarelor de bule fine, Facultatea de Inginerie Mecanică și Mecatronică, Universitatea POLITEHNICA din București(2011).

[7] Pătulea, Al. S.: Influenţa parametrilor funcţionali şi arhitecturii generatoarelor de bule fine asupra eficienței instalaţiilor de aerare, Doctoral Thesys.

[8] Mateescu, G., Marinescu, A., Băran, N.: A new Constructing Fine Bubles Generators, Buletin of The Transilvania University of Braşov, vol.2, pp.359-367, Braşov,(2009).

[9] Băran, N., Băran,Gh.,Mateescu, G.: Research Regarding a New Type of Fine Bubble Generator, Revista de Chimie, vol.61, nr.2, pp.196199,(2010).

[10] Pătulea, Al., Căluşaru, I.M., Băran, N.: Researches regarding the measurements of the dis-solved concentration in water, Advanced Materials Research, Trans Tech Publications, Switzerland, vols. 550-553, pp. 3388-3394,(2012). 